\title{
Culturally Competent and Socio-politically Conscious Teaching: A Teacher Educator Works to Model the Journey to Critical Cultural Competence
}

\author{
Diane Alice Ross \\ Otterbein College \\ USA
}

The purpose of this article is to present the self-study of a teacher educator who

is concerned about cultural competence, socio-political consciousness, social

justice, and peace in her preparation of teacher candidates. She recounts her

experiences at the European Peace Institute (EPU) in Stadtschlaining, Austria,

and how experiences with these students impact her perspective on teacher

education in the United States. Sharing the voices from students at EPU

provides a means of consciousness-raising for the teacher educator. She

provides examples of ways to bring a more culturally competent and socio-

political awareness to teacher education programs in the United States.

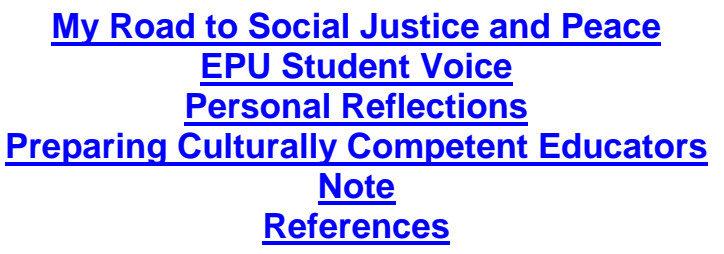

Preparing teachers for cultural competency has become almost an official doctrine among teacher educators (Ladson Billings, 2001; Sleeter, 2001; Vavrus, 2002). Culturally responsive teaching requires deep reflection into the issues of cultural competence and socio-political consciousness. Culturally competent teachers understand the complexity of culture and its role in education, take responsibility for learning about students' culture and community, use student culture as a basis for learning, and promote a flexible use of students' local and global culture. Socio-politically conscious teachers know the larger socio-political context of the school, community, nation, and world and have knowledge of the social and political realities in which they live (Gay \& Kirkland, 2003; LadsonBillings, 2001; Gay, 2000). As teacher educators, we are asked to ensure that our teacher candidates are prepared to be culturally competent and culturally responsive. The question that this essay attempts to address is: how do teacher educators prepare themselves for the work of preparing culturally competent and socio-politically conscious teachers?

As a teacher educator who puts social justice and peace at the forefront of her practice, cultural competence and socio-political consciousness are the foundation of my work. The following article is a self study of how I, as a teacher 
educator, came to understand more deeply the concepts of cultural competence, socio-political consciousness, social justice, and peace. The first step to developing cultural competence and socio-political awareness is to be aware of the social construction of our own identities and that of our students and to realize that identity is shaped in cultural experiences. Self-reflection is an important part of professional development for our students and for us (Lee, 2005; Robertson \& Webber, 2000). The intent of this praxis essay is to provide an example of this reflexive process from the perspective of a teacher educator and then to translate these ideas into specific suggestions for teacher educators.

Philosophically and methodologically, my practice has been informed by Clark Moustakas' (1994) concept of heuristics. This article draws upon that same methodological framework. Heuristic, which comes from the Greek word heuriskein, means to discover or to find. The methodological processes in heuristic study use qualitative raw data that reach at the essence of a person's experience. "Situations, events, conversations, relationships, feelings, thoughts, values, and beliefs" are at the core of the heuristic research (Moustakas, 1994, p. 38). The researcher can use raw data, direct quotes, detailed descriptions, and case studies to discover the meaning of the experiences in their world. Heuristics encompasses autobiography, phenomenology, and case study. Heuristic inquiry allows for the combination of intellect, emotion, and spirit. It calls for the researcher to see the distinctive qualities, yet holistic nature, of a phenomenon in a disciplined fashion. Through this writing, I am working to reflect on my own understandings of cultural competence within the phenomenon of being immersed in a global, multicultural experience at the European Peace University. I use personal reflection and the case study of others to gather the essence of this experience.

The power of true learning occurs from being immersed in the community (Sleeter, 2001; Villegas \& Lucas, 2002). It was being immersed in a global community focused on social justice and equity that made me understand the work of preparing culturally competent teachers.

\section{My Road to Social Justice and Peace}

I am a teacher educator at Otterbein College in Westerville, Ohio. I taught middle school for 17 years and have been in higher education for 11 years. On a recent sabbatical, I had the opportunity to travel to Austria and teach at the European University Center for Peace Studies. My association with Ohio Commission on Dispute Resolution and Conflict Management connected me to a peace program in Austria. I planned a visit to the center during a sabbatical but, after contact with the director, was invited to teach in this institution for a oneweek seminar.

The European University Center for Peace Studies (EPU) is located in Stadtschlaining, Austria, a beautiful, small and quiet medieval town in the foothills 
of the Alps between Vienna and Graz. It has a 700-year-old castle hosting the EPU Offices and a peace museum, and a famous peace library. It was founded in 1988 by its current president, Dr. Gerald Mader. In 1995 it received the UNESCO Prize for Peace Education. The EPU program is designed to provide students with the intellectual skills to analyze conflicts and their underlying causes, with practical skills in conflict transformation and peace building, and with the motivation to do everything in their capacity to help create a better world. It seeks to enable and motivate students to help build a more peaceful, equitable and just global society in harmony with nature.

For my week seminar, I chose to teach a course called Social Justice and Equity in Education. I came to the EPU, feeling confident that I had begun to get a grasp of the issues surrounding peace and justice in educational settings. I came ready to talk about the problem of the United States' federally mandated curriculum and high stakes testing and how that leads to intolerance, injustice, and inequity. I came ready to talk about how this impacts students of color, English second language learners, and low socio-economic students. I knew that issues of race and school segregation were still problematic, and I came prepared to share the ongoing apartheid in schools in the United States today. I had examples of how American teachers address issues of war and violence in their classrooms. I came ready to encourage students to be introspective and consider their own educational journeys and their effect on teaching and learning. However, I was completely unprepared for the vast cultural differences and myriad of cultural experiences that I would participate in during this weeklong experience.

The Haus International serves as a student hotel during study at EPU. During my time there, 40 people lived, studied, ate, danced, and debated into the late hours about peace and justice from their multiple perspectives. These students came from countries around the world, such as Pakistan, Malawi, Cape Verde, Nepal, Iran, Canada, Lebanon, Malawi, Italy, Kyrgyzstan, Myanmar, Nigeria, Kenya, Jamaica, Peru, Uganda, Austria, Indonesia, South Africa, Norway, Moldova, Zimbabwe, and the United States. They ranged from their midtwenties to their fifties. They had traveled the world over and were translators, professors, freelance journalists, social workers, conflict resolution resource managers, psychologists, and elementary school teachers. They worked for non-governmental agencies such as UNESCO, the National Peace Campaign, the Pearson Peacekeeping Centre, the Service and Leadership Team (SALT), United Action for Children, Action for Development (ACFODE) in Uganda, the Conflict Resolution and Management Centre, the African Party of Independence of Cape Verde (PAICV), the Norwegian Humanist Association, Community Peace Building for Zimbabwe Civic Education Trust, and the Center for Nonviolent Communication (CNVC). 


\section{EPU Student Voices}

I had come to the EPU with many well researched topics around issues of racism, violence, social justice, and peace. However, what I did not come with was knowledge or experience of these issues from a global perspective, nor the cultural competence and socio-political awareness to translate these incidents into my own work as a teacher educator. I had collected pictures, ideas, and visions through a very narrow window into the world. The students at EPU opened my eyes. These stories helped me come to a richer understanding of the underlying foundations of cultural competence. The following are some of my students' stories and how they moved me along my self-reflective path.

\section{Pierre (Uganda)—Violence and War}

I met Pierre on Sunday night, the first night that I was at the Haus International. He is a quiet, gentle man from Uganda. He has a disarming smile and a sweet disposition. On the third day of class, I asked the students to share a little about their own educational experience. Pierre wrote ${ }^{1}$ :

In my case for example, I used to walk six kilometers to and from the school on daily basis. This had a serious impact on me as I had to starve throughout the day since I could not go back home to have lunch and later on come back to school in time, so often I tended to lose concentration and all this was in my early days of elementary school.

In Uganda among the Banyankole tribe, the rights of the girl child to education is something that has been given low attention. However, there are many loopholes that affect girl child's right to education despite massive campaign against gender imbalance in education provided in Uganda. Among the Banyankole culture, the education for boys is more valued than that of the girls for instance comparing the enrollment percentage of years 1992 and 1999 is quite alarming, for girls was 46.1 per cent against 82.0 per cent for boys, and 55.7 per cent against 85.5 per cent respectively (World Bank, 2002).

Culturally, the girl child in Banyankole tribe is seen as the source of wealth to her family and source of the domestic labour to the family she join for marriage. To sum up the need for the above expectations the girl child is forced to marry earlier in order for the parties to benefit. Staying longer in schools for education needs means a delay in cultural performances.

In a quiet voice, Pierre then recounted his story of being taken away from his family and his school at the age of 12 to be a child soldier. He talked about losing his childhood and then was hesitant to explain much more than that about these years. I struggled to hear what he said because of his quiet voice, struggling English, and strong Ugandan accent, but that misunderstanding was 
nothing compared to my struggle to understand what it meant for a child to be pulled from school and be indoctrinated into a life of violence. I did not understand how this young man had lived with years of pain with no parents and no opportunity for schooling and yet was standing here in front of me articulate, loving, and working towards social justice in his own country.

\section{Nakilini (Malawi)—Protect and Respect Children and Youth}

Naklini is a small, shy woman from Malawi. She was not in my class but sought me out to talk during breaks and dinner. She also asked me to work with her on two of her term papers. Through her words, I began to see the reality of children who are not receiving an education and who would suffer death for the opportunity. Nakilini wrote:

In Malawi, free primary education was introduced in October 1994 following announcement in June by the newly elected government of $\mathrm{Dr}$. Bakili Muluz. On a sad note, in 2005 a tree fell down with a thud, attracting the attention of hundreds of people including children, teachers and the surrounding neighborhood. Seconds later, children wailed and many rushed to the scene only to discover that the fallen tree had killed two pupils and injured several others who were learning under it. Due to the large number of the pupils, students had to stand outside of the classroom to hear the lesson. The teacher could not control all of the students. Also, the teachers found it difficult to mark the work of 63 pupils because the ratio of teacher to pupils came to 1:63.

\section{Ahmad (Pakistan)-Gender Justice}

Ahmad is a tall lean man with dark hair, dark eyes, and often a sad and troubled countenance. He joined my class, but it seemed like it was done rather haltingly and with some unwillingness. In the class introductions, Ahmad stated that he was here at the EPU to get his degree in peace work because he had gotten his degree as a military man and there were no jobs. Throughout the class he seemed angry, disillusioned, and challenged much of what I had to say. He was always articulate and shared his opinions and perspectives freely. I was often concerned when leaving the class whether I had made any impact on him that day. But, it was not until the end of my teaching that I began to understand Ahmad's cultural perspective, great integrity, and deep commitment to his peace work. Of all of the students that I had worked with, at the end, he showed me the most by his courage to challenge the cultural norms surrounding women in his country. Gender bias never came home so intensely as when I worked with him on his research on women's role in Pakistan. In his words, we see the issue of gender bias with deep intensity. Ahmad wrote:

Violence against women is a worldwide problem because it includes half of the humanity. Women all over the world face multiple forms of violence 
just because of being women. There are many cultural and structural causes which provide sound basis for the continual perpetuation of violence against women all over the world. Pakistani society is a true example of manifesting this violence where there are deep-seated beliefs based on culture and traditions, norms and social institutions that legitimize and therefore perpetuate violence against women. Women are considered as personal properties of men and men control every aspect of lives of women including their behaviour and movements. Men have the right to make decisions, and women have to follow their decisions in family, tribe, community and society.

\section{Other Student Stories} and Ahmad.

Other students' stories are just as compelling as those of Pierre, Nakilini,

Burma is mainly a Buddhist country. The Buddhist concept of tolerance and obedience are mainly promoted in all forms. Every morning, school children have to chant Buddhist prayers. Military looks wild from all perspectives but the military doesn't want people to be wild and aggressive but to obey and be submissive. Those are simply promoted in school curriculum and teacher training under the name of "traditions and culture." (Mya from Burma)

However, our teachers need greater respect in almost every domain in order for that to happen. More money, greater flexibility, more challenging curriculum, more creative thinking, more concern for children's feelings and constructive ways to express them, more kindness and consideration, more love. This places a tremendous demand on the teacher and unless there are structures in place to support the teacher's efforts, there is not much possibility of truly educating our children. I can't think of one thing that is more important than nurturing and supporting our children and the teachers that instruct them. (Joseph from California, USA)

There is obviously a reason, an ideology if you will, behind why individuals do what they do. One thing would be to try to change the ideology of the politicians, another would be to try to educate enough brave people to stand up to the system and the parents, stand up to the fear of standing out, so that when the system comes down on them, they will constitute such a force that if they packed their things and left there would not be enough teachers left. (GuitA from Iran)

EPU has provided an opportunity for us to broaden our circle of care and challenge our own America-centric worldview because we were in an isolated environment that emphasized cultural exchange and learning by peaceful means. Such an environment is beyond rare. Any global 
perspective that American students may foster will be necessarily limited if they don't first learn to be critical of their own culture. If students aren't given the opportunity to think about their own lives critically, tell their own stories, celebrate their uniqueness, reflect on the complexity and dynamism of their own identities, then they will not have the self-respect that is necessary to care about the suffering that is occurring within and beyond our borders. I believe that the ongoing process of understanding our selves in relation to systems of privilege and power is necessary for this kind of connection to occur. (Sue from California, USA)

These are the people who raised my cultural competence and sociopolitical awareness. These are the voices that move me forward along the path to social justice and peace.

\section{Personal Reflections}

Through this experience, I gained a new perspective about my work in the United States and a growing desire to continue to understand the lack of consistent quality education available to children in the world. I learned much about what I did not know about the impact of culture on teaching and learning.

Pierre helped me to realize that issues of war and violence do not just affect our students from afar but can affect young people directly. I began to consider our role as teachers for social justice and equity and the role that we can play in our schools in the United States so that Pierre's story never is brought to fruition for another child in any country. I am concerned about the visual manifestations of militarism that are seen in our schools. Examples of this were recounted in the journal Rethinking Schools: National Guard calendars on the walls in the guidance office, "Go Army" lanyards holding the faculty bathroom keys, large cut-out military figures in the hallway, junior reserve Officer Training Corps displays with pictures and trophies, and Marine Corps insignia on the preschool dedication photo in the school office (Jordan, 2003). I see our role as culturally competent, socio-politically conscious teachers to question the political and social policies that are guiding our schools and to work to widen circles of care with our students.

Pierre's words also remind me of the call of Rosaldo (1993) where he challenges us not to impose our own values and concepts of cultural normality onto others because they will probably not apply. Our job as teacher educators is to understand that culture determines how people see and act on their everyday life, and this may only make sense in their own context and in their own terms.

Nakilini and Pierre challenged my understandings of the rights of children through different cultural lenses. The concept of equal access to education was made so much more powerful in Nakilini's discussion of education in Malawi. 
The first day of teaching at the EPU, I had discussed the history of public school. How many times had I spoken to my teacher candidates in the United States about the power and the right of public education? However, it was not until I heard from Nakilini that I truly understood the meaning of victimization of children and the impact of accessible education on the lives of all children.

At the EPU, I taught about isms in the United States' schools: racism, sexism, etc. But never did I have an understanding of the true effect of what bias and intolerance could lead to. What I had mistaken in Ahmad at the beginning of the class as anger towards me or the class was in fact, I believe, a genuine internal struggle to deal with the cultural values of women in roles of authority as well as his distrust of Americans. After months of emails to work on his master's project, he sent me one final message. He stated that knowing me and working with me had changed his views about women and the United States. Ahmad taught me about my role as a teacher educator who believed in social justice and equity. As teacher educators we are mandated to make multicultural education a part of our preparation of teachers for today's society. Yet never has it been more difficult than in today's post 911 culture. The growing attacks on people of Middle Eastern descent, Asian decent, and Latino descent give evidence of this.

Mya from Burma challenged my questioning of a nationally mandated curriculum. She reminded how the impact of religious thought can narrow curriculum with an even greater intensity than we see in the United States in our standardized curriculum and high stakes testing. Joseph from the United States (California) encouraged me to consider the role of language in our culture. One night he introduced us to the concepts of non-violent communication skills. He reminds me that to reach social justice, equity, and peace, non-violence must be a part of our classrooms. GuitA from Iran showed me the courage of a woman fighting for the rights of others and her right to be heard in a male-dominated society. Sue from the United States acknowledges that my struggle to find myself in relation to this cultural struggle is essential. It is only in truly learning about oneself that we can be open to hearing the voice of others.

My knowledge and research were essential to my teaching success with the students at the EPU. Yet, what I learned there was more imperative to my own success as a teacher educator. The students that I met came from 30 different countries, and each of them had stories to tell of their educational experiences. These were stories that I may have listened to before but had not heard through the eyes of those who had lived these experiences. The recruitment of child soldiers in Africa, caning by teachers in Kenya, the inequality of the girl child's education in Uganda, the inconsistency of opportunities for women in Pakistan and Lebanon, the desire of countries to be more Westernized and yet in doing so negating their own unique needs and situations all pushed my own social construction of cultural competence. 
I did not come prepared for the overwhelming feeling of how my knowledge of education was so small and narrow in regards to the truly multicultural experience at EPU. To understand the United States and its perspectives was such a small sliver of the knowledge necessary to understand the concepts of cultural competence, peace, justice, and equity in education. Also, I realized that the American's narrow perspective was not shared by people from other countries but was uniquely an American perspective. Many Europeans have concerns about American imperialism, dominance, and entitled privilege. I came to understand that Europeans are aware of the implications of world violence and conflict in their lives because of geographic proximity and cultural values of community. I was challenged by the EPU students to consider the USA's allusion that even in the 21st century, with our geographic isolation and capitalistic attitude, we can become apathetic to world violence and conflict. So how do I take this knowledge and apply it to my practice as a teacher educator working towards cultural competence?

\section{Preparing Culturally Competent Educators}

It is widely recognized that there is a changing demographic population in our schools presently. In 1994, the enrollment in public elementary and secondary schools was $65.6 \%$ White, $16.7 \%$ Black, $13 \%$ Hispanic, $3.6 \%$ Asian, and $1.1 \%$ Native American. In 2004 the numbers showed a decrease in White students and a growth in the students of color; $57.9 \%$ White, $17.3 \%$ Black, 19.2\% Hispanic, 4.5\% Asian, and 1.2\% Native American. (National Center for Education Statistics, 2006). The accelerating growth of nonwhite public school students is misaligned with the lack of racial diversity of the teacher work force (Orfield \& Lee, 2006).

In the United States, teacher candidates are not only predominantly White women but also come from a completely different cultural background than many of their students. Adding to this, they bring little to no cross-cultural background, knowledge, or experience. Therefore, education around issues of cultural competence is complicated (Barry \& Lechner, 1995; Gilbert, 1995; McIntyre, 1997; Valli, 1995).

Not only is there a clear cultural mismatch in our present educational system; there is also a clear misunderstanding of the basic concepts of culture. Culture lends significance to human experience by selecting from and organizing

it. Culture does not refer to music, food, and art museums but rather the way that people make sense of their everyday lives (Rosaldo, 1993). Therefore, understanding cultural differences requires our teacher candidates to learn not to impose their own values and concepts of cultural normality onto others. However, as teacher educators we cannot expect our students to be able to make this cultural translation without having direct multicultural experiences (Sleeter, 2001; Willard-Holt, 2001). 
The cultural mismatch that is seen in public schools in the United States is, in part, perpetuated because of the current demographic situation in teacher preparation programs. Therefore, teaching issues of cultural competence and socio-political awareness is complicated in our current teacher education institutions. If we believe that "culturally inclusive education is inseparably linked to social justice," then we are challenged in our present system to reconsider our work in teacher education (Jennings, 1995, p.1). Yet, the conversation about teachers and their lack of cultural competence has not highlighted the issues of teacher educators and their cultural homogeneity. Despite the ongoing verbal commitment to social justice and equity, many teacher educators never find the opportunities to act on these commitments (Ladson-Billings, 2005).

Alfie Kohn (2001) states that our work is to help our students locate themselves in "widening circles of care that extend beyond self, beyond country, to all humanity" (p. 5). I believe that there are a multitude of things that teacher educators can do to broaden their circles of care and to stay connected to the issue of cultural competence, socio-political consciousness, social justice, and peace. The following resources have been beneficial to me in my work, as I tried to become more culturally competent so as to prepare culturally competent and socio-politically conscious teachers.

1. Check out the resources for teaching and learning at Teaching Tolerance, a subdivision of the Southern Poverty Law Center (www.tolerance.org).

2. Check out the Ohio Commission on Dispute Resolution and Conflict Management. They have extension programs and materials for teachers and teacher educators (http://disputeresolution.ohio.gov/).

3. Learn what kind of programming is happening around the world in the area of global education at Discovery Global Education Network (http://www.discoveryglobaled.org/).

4. Find out about the initiative that encourages all children to have access to a laptop around the world, even in the most remote areas, at One Laptop Per Child (http://laptop.org/)

5. Invest in the Rethinking Schools magazine to challenge your preconceived notions about teaching and learning (http://www.rethinkingschools.org/)

6. Subscribe to Encounter: Educating for Meaning and Social Justice (https://great-ideas.org/enc.htm).

7. Visit the Peace Education Center (http://www.tc.edu/PeaceEd/iipe/index.htm).

8. Connect students to the European Peace Studies (http://www.aspr.ac.at/).

9. Connect students to the Conflict Resolution Education Center (http://www.creducation.org./). 
10. Find out what is offered at Global Issues Resource Center (GIRC) at Cuyahoga Community College (http://www.tric.edu/COMMUNITY/GLOBALISSUES/Pages/Home.aspx).

11. Check into student teaching in a different culture or country:

a. Go Abroad (http://www.goabroad.com/).

b. Global Student Teaching (http://educatorsabroad.org/).

c. Philadelphia Center (http://www.philactr.edu/).

When I left the EPU, my students there told me that my job was to go back and to tell their stories to my students. They believed that I could work to combat that imperialistic, isolated attitude found in America by helping teachers understand global perspectives and teach those perspectives to their students.

In a recent email, Jamile from Lebanon summed up what I believe about our work as teachers who are culturally competent, socio-politically conscious and who believe in social justice and peace.

Although I still have a lot of courses to take at university, I have decided that it's time for me to do something meaningful for Lebanon through peace education. At university I have learned one basic mathematical formula: ONE HUMAN LIFE = ONE HUMAN LIFE. And this has been my main guiding principle.

\section{Note}

1. The quotes from students' writings are not edited for this manuscript.

\section{References}

Barry, N. H., \& Lechner, J. V. (1995). Preservice teachers' attitudes about and awareness of multicultural teaching and learning. Teaching and Teacher Education 11(2). 149-161.

Gay, G. (2000). Culturally responsive teaching: Theory, research and practice. New York: Teacher's College Press.

Gay, G., \& Kirkland, K. (2003). Developing cultural critical consciousness and self-reflection in preservice teacher education. Theory into Practice, 42(3), 1-8.

Gilbert, S. L. (1995). Perspectives of rural prospective teachers toward teaching in urban schools. Urban Education 30(3), 290-305.

Jennings, T. E. (1995). Developmental psychology and the preparation of teachers who affirm diversity: Strategies promoting critical social consciousness in teacher preparation programs. Journal of Teacher Education, 36(4), 1-13. 
Jordan, H. (2003). No child left unrecruited. Rethinking Schools Online. Retrieved August 21, 2007, from http://rethinkingschools.org/war/readings/unre173.shtml

Kohn, A. (2001). Fighting the tests, Phi Delta Kappan, Retrieved March 22, 2008, from http://www. alfiekohn.org/articles.htm\#null

Ladson-Billings, G. J. (2001). Crossing over to Canaan: The journey of new teachers in diverse classrooms. San Francisco, CA: Jossey-Bass.

Ladson-Billings, G. J. (2005). Beyond the big house: African American educators on teacher education. New York: Teachers College Press.

Lee H. J. (2005). Understanding and assessing preservice teachers' reflective thinking, Teaching and Teacher Education, 21, 699-715

Mclntyre, A. (1997). Making meaning of whiteness. Albany, NY: State University of New York Press.

Moustakas, C. (1994). Phenomenological research methods. Thousand Oaks, CA: Sage Publications.

National Center for Education Statistics (2006), Common Core of Data (CCD)— Table 4. State nonfiscal survey of public elementary/secondary education, 1994-95 and 2004-05. Washington, DC: U.S. Department of Education.

Orfield, G., \& Lee, C. (2006). Racial transformation and the changing nature of segregation. Cambridge, MA: The Civil Rights Project at Harvard University.

Robertson J. M., Webber C.F. (2000). Cross-cultural leadership development, International Journal of Leadership in Education, 3(4) 315-330.

Rosaldo, R. (1993). Culture \& truth: The remaking of social analysis. Boston: Beacon Press.

Sleeter, C. E. (2001). Preparing teachers for culturally diverse schools: Research and the overwhelming presence of whiteness. Journal of Teacher Education, 52(2), 94-106.

Valli, L. (1995). The dilemma of race: Learning to be color blind and color conscious. Journal of Teacher Education, 46(2), 120-129.

Vavrus, M. (2002). Transforming the multicultural education of teachers: Theory, research and practice. New York: Teachers College Press.

Villegas, A. M., \& Lucas T. (2002). Educating culturally responsive teachers: A coherent approach. Albany, NY: State University of New York Press.

Willard-Holt, C. (2001). The impact of a short-term international experience for preservice teachers. Teaching and Teacher Education, 17, 505-517.

World Bank. (2002). Achieving universal primary education in Uganda:The 'Big Bang' approach. Human Development Network Education Notes. Retrieved August 25, 2007, from 
Vol. 10, No. 1

http://siteresources.worldbank.org/EDUCATION/Resources/EducationNotes/EduNotesUganda.pdf 